Poetics of Emptiness 
This page intentionally left blank 


\section{Poetics of Emptiness}

Transformations of Asian Thought in American Poetry

JONATHAN STALLING

Fordham University Press

NEW YORK 2010 
(C) 2010 Fordham University Press

All rights reserved. No part of this publication may be reproduced, stored in a retrieval system, or transmitted in any form or by any means-electronic, mechanical, photocopy, recording, or any other-except for brief quotations in printed reviews, without the prior permission of the publisher.

Fordham University Press has no responsibility for the persistence or accuracy of URLs for external or third-party Internet websites referred to in this publication and does not guarantee that any content on such websites is, or will remain, accurate or appropriate.

Library of Congress Cataloging-in-Publication Data

Stalling, Jonathan.

Poetics of emptiness : transformations of Asian thought in American poetry / Jonathan Stalling. - 1st ed.

p. $\mathrm{cm}$.

Includes bibliographical references and index.

ISBN 978-0-8232-3144-7 (cloth : alk. paper)

1. American poetry-Chinese influences. 2. Emptiness (Philosophy)

3. Philosophy-East Asia. 4. Poetics. I. Title.

PS159.C5S73 2010

$811.009{ }^{\prime} 384-\mathrm{dc} 22$

2010005596

Printed in the United States of America

$121110 \quad 54321$

First edition

A book in the American Literatures Initiative (ALI), a collaborative publishing project of NYU Press, Fordham University Press, Rutgers University Press, Temple University Press, and the University of Virginia Press. The Initiative is supported by The Andrew W. Mellon Foundation. For more information, please visit www.americanliteratures.org. 
For Amy Noél Stalling 
If we take an instantaneous photograph of the sea in motion, we may fix the momentary form of a wave, and call it a thing; yet it was only an incessant vibration of water. So other things, more things, apparently more stable, are only large vibrations of living substance; and when we trace them to their origin and decay, they are seen to be only parts of something else. And these essential processes of nature are not simple; there are waves upon waves, process below processes, systems within systems; - and apparently so on forever.

-ERNEST FENOLLOSA, "THEORY OF LITERATURE” 